\title{
気管支喘息の病態におけるヒスタミンの役割と抗ヒスタミン薬の臨床的有用性の再検証
}

\author{
山内広平, ${ }^{*, a}$ 鹿内俊樹, ${ }^{a}$ 中村 豊, ${ }^{a}$ 小林 仁, ${ }^{a}$ 小笠原正人, ${ }^{b}$ 前山一隆 $b$
}

\section{Roles of Histamine in the Pathogenesis of Bronchial Asthma and Reevaluation of the Clinical Usefulness of Antihistamines}

\author{
Kohei YAMAUCHI, ${ }^{*, a}$ Toshiki ShIKANAI, ${ }^{a}$ Yutaka NAKAMURA, ${ }^{a}$ \\ Hitoshi KobAYASHI, ${ }^{a}$ Masahito OGASAWARA, ${ }^{b}$ and Kazutaka MAEYAMA ${ }^{b}$ \\ ${ }^{a}$ Division of Pulmonary Medicine, Allergy and Rheumatology, Department of Internal Medicine, \\ Iwate Medical University School of Medicine, 19-1 Uchimaru, Morioka 020-8505, Japan, \\ and ${ }^{b}$ Department of Pharmacology, Ehime University Graduate School of Medicine, \\ 454 Shitsukawa Toon, Ehime 791-0295, Japan
}

(Received August 31, 2010)

\begin{abstract}
Histamine has been reported to play an important role in pathogenesis of bronchial asthma. However, H1-blockers are not recommended as the first drug for asthma therapy in the guidelines. Histamine may play various roles in allergic airway inflammation through the $\mathrm{H} 1$ receptor (H1R), H2R, and H4R in immune cells including T lymphocytes and dendritic cells. We therefore evaluated its role in allergic airway inflammation with the use of histamine-deficient mice. The results suggested that histamine plays a role in the prevention of goblet cell hyperplasia. Organic cation transporter-3 (OCT-3) is thought to be a transporter of histamine. Polymorphism of OCT-3 $\{\mathrm{R} 120 \mathrm{R}(\mathrm{T} / \mathrm{C})\}$ was associated with the severity of asthma. Recently, it has been proposed that both asthma and allergic rhinitis should be treated as a single airway disease. Comorbidity of asthma and allergic rhinitis is very high (70-80\%) and they share similar allergic inflammation. H1-blockers are recommended as first-line drugs to treat allergic rhinitis in the guidelines. Therefore H1-blockers are strongly recommended for patients with both asthma and allergic rhinitis.
\end{abstract}

Key words - histamine; H1 blocker; asthma; allergic rhinitis; organic cation transporter-3

ヒスタミンは古くから知られた即時型アレルギー 反応の化学伝達物質であり, 気管支喘息の病態にお いても重要な役割を果たしていると考えられてき た．事実，気管支喘息患者の肺胞洗浄液中のヒスタ ミン濃度は健常人と比べ有意に高いことが報告され ている. 即時型アレルギー反応により生じると考え られているアレルギー性鼻炎や莖麻疹に対して H1 受容体拮抗薬（H1RA）は臨床的に有効な薬剤とし てその使用が推奨されている。一方，H1RA は気 管支喘息の治療ガイドラインでは補助的な使用が推 奨されているのみで, 治療薬剤としての地位は高く ない. 気管支喘息の治療薬の第一選択は吸入ステロ

$a$ 岩手医科大学医学部呼吸器・アレルギー・膠原病内科 （T020-8505 盛岡市内丸 19-1), $b^{b}$ 愛媛大学大学院医学 系研究科統合生体情報学講座薬理学（T791-0295 愛媛 県東温市志津川 454)

*e-mail: kyamauch@iwate-med.ac.jp

本総説は, 日本薬学会第 130 年会シンポジウム S48 で 発表したものを中心に記述したものである.
イド剤であり, 加えて長時間作動型 $\beta_{2}$ 刺激薬，テ オフィリン，短時間作動型 $\beta_{2}$ 刺激薬などの気管支 拡張薬, そしてロイコトリエン受容体阻害薬がガイ ドラインで推奨されている (Table 1)。H1RA は気 管支喘息の治療薬として効果がないのだろうか.

Figure 1 にみられるように，アトピー性気管支喘 息患者の気管支肺胞洗浄液中のヒスタミン濃度は健 常者に比べ優位に高いことが報告されている. ${ }^{1)}$ さ らにヒスタミンで惹起した気道閉塞 (FEV1の低下) は H1RA であるテルフェナジンで完全に回復す る。一方抗原吸入による気道閉塞は部分的な抑制に 留まる（Fig. 2). 2) さらに抗原吸入による即時型及 び遅発型喘息反応に対してロイコトリエン受容体阻 害薬（LTRA）と H1RA の効果を比べた報告があ り，LTRAの気道閉塞に対する阻害効果が H1RA を上回っている(Fig. 3).3)このような経緯で LTRA は喘息治療ガイドラインの主要な治療薬剤 であり，H1RA は補助的な役割に留まっている. 
Table 1. Guideline for Prevention and Management of Asthma

（喘息予防・管理ガイドライン 2009）

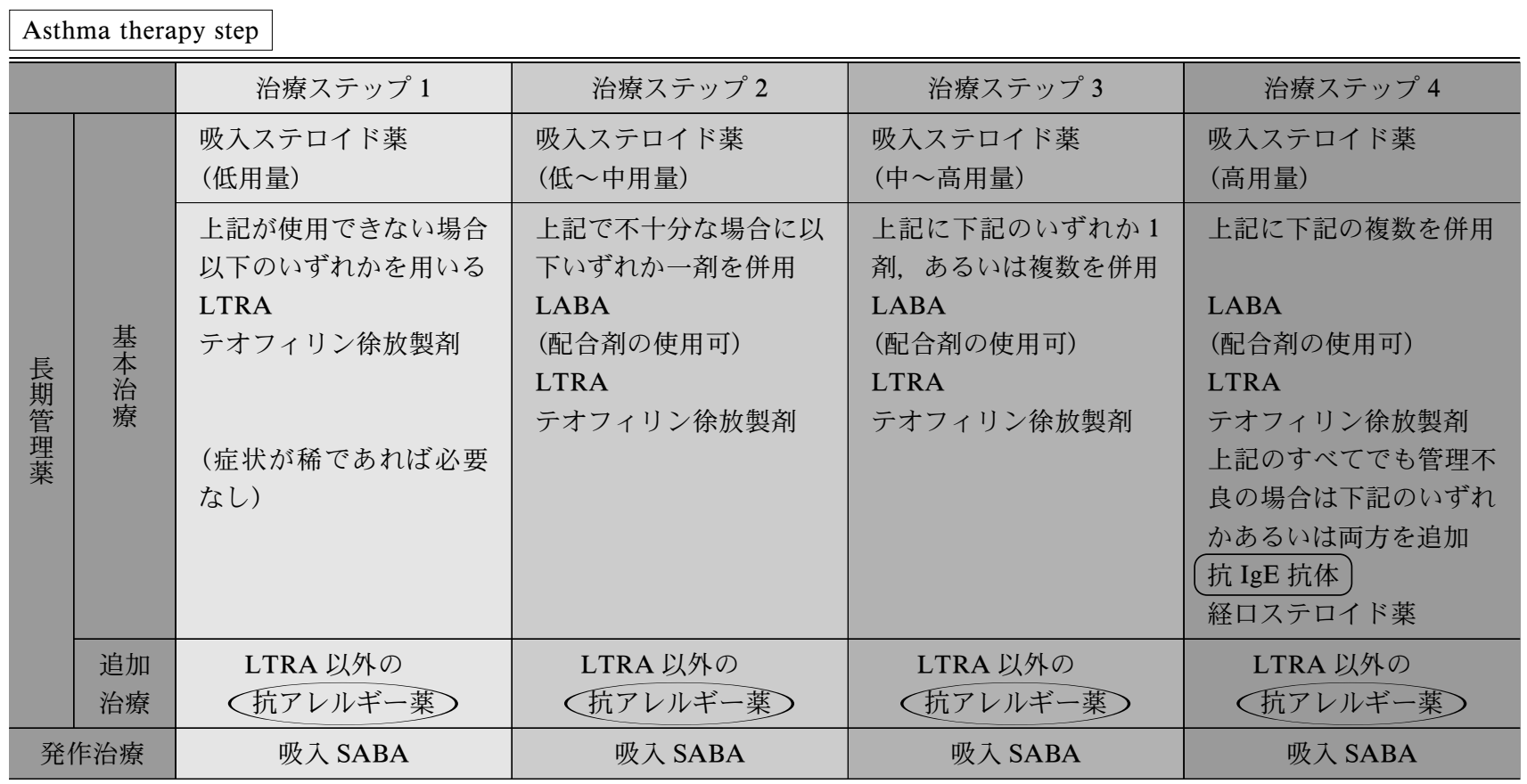

LTRA: leukotriene receptor antagonist, LABA: long-acting beta2 agonist, SABA: short-acting beta2 agonist. Anti-allergic drugs include inhibitors of chemical mediator release, (H1 blockers, anti-thromboxane A2 drugs and anti-Th2cytokine drugs.

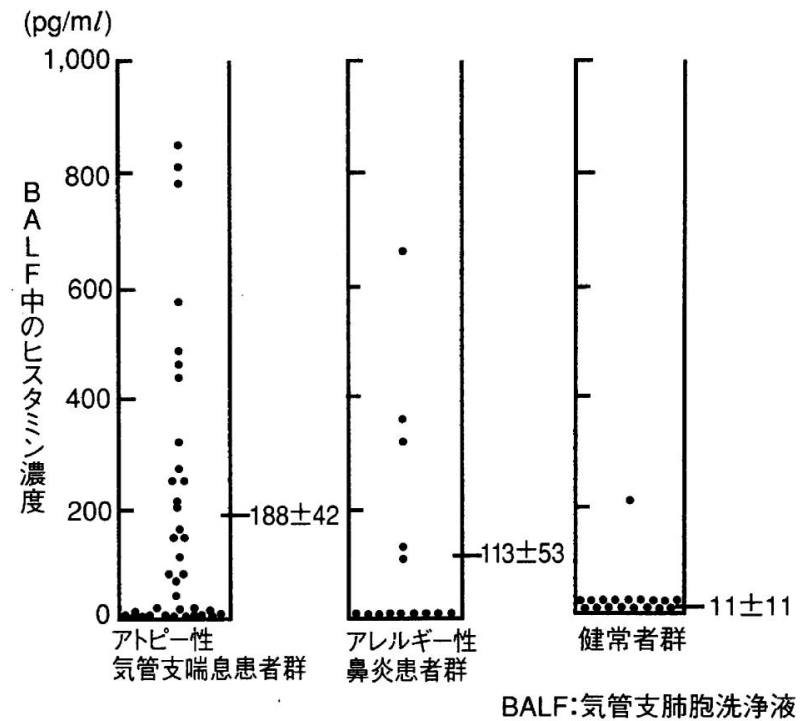

Fig. 1. Histamine Concentration in Bronchoalveolar Lavage Fluid (BALF) from the Patients with Bronchial Asthma

The histamine concentration in BALF from the patients with atopic bronchial asthma is significantly higher compared to those of the patients with allergic rhinitis and healthy controls. $(p<0.05$; Tukey-Kramer Test).

確かに気道拡張効果という点でみると LTRA は H1RA を上回っているが，最近オマリズマブとい う抗 IgE 抗体がアトピー型の重症喘息に推奨され て，優れた臨床効果を示している．このことはマス

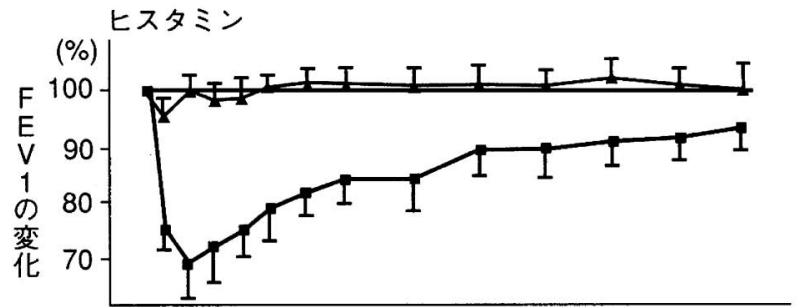

(\%) 抗原吸入

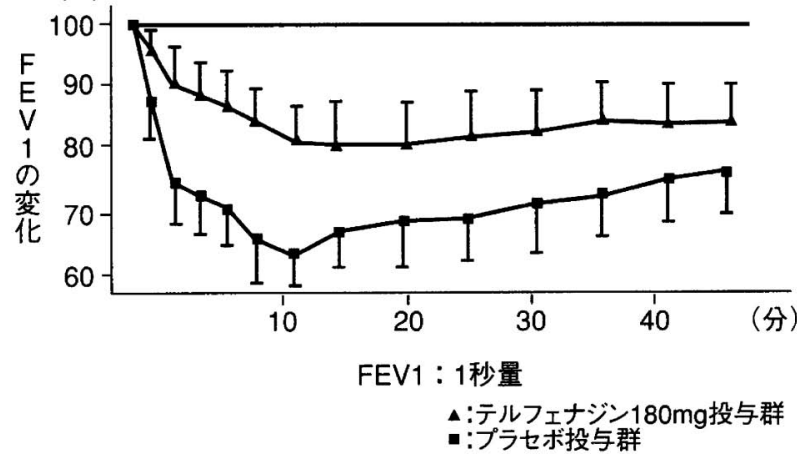

Fig. 2. Effects of Terfenadine on Airway Obstruction Induced by Histamine and Allergen

Terfenadine $(180 \mathrm{mg})$ inhibited bronchial contraction by histamine completely and reduced airway obstruction by antigen inhalation significantly.

ト細胞が気管支喘息の病態に重要な役割を果たして いることを再確認させてくれた，H1RAの気道拡 張効果も各気管支喘息患者によって大きく異なり， 


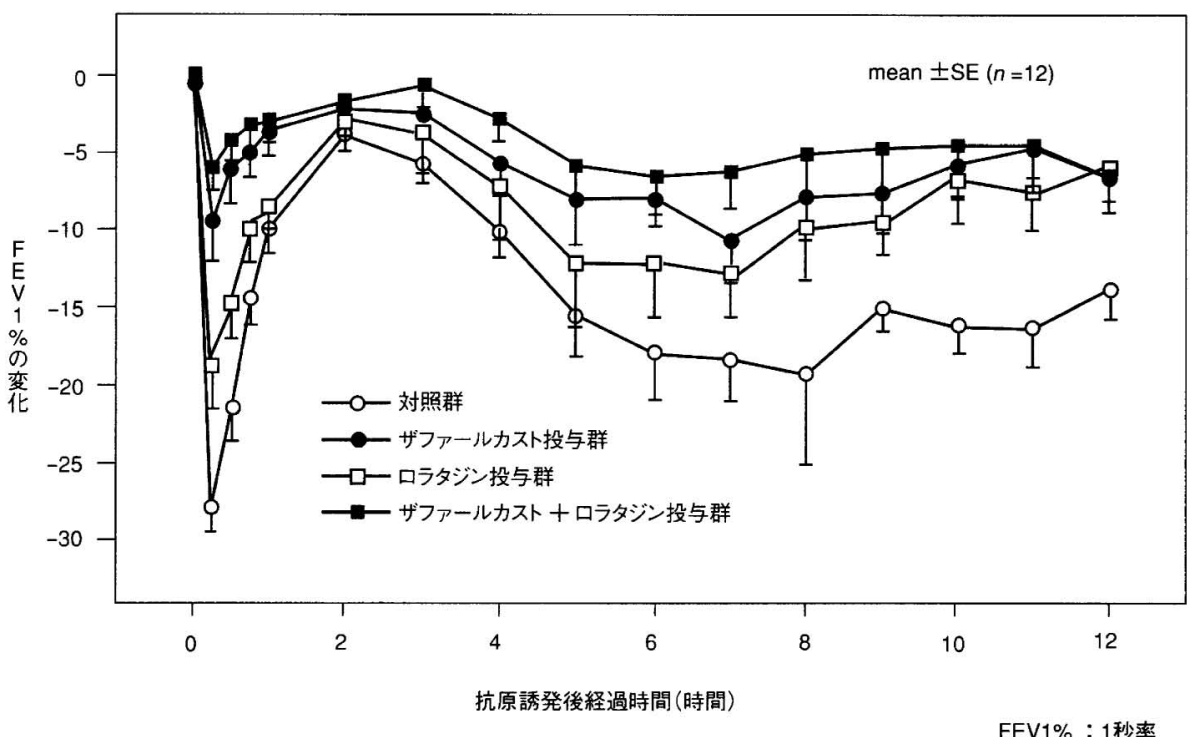

Fig. 3. Effects of H1 Blocker: Loratadine, Leukotriene Receptor Antagonist: Zafirlukast and Their Combination on Immediate and Late Asthmatic Responses

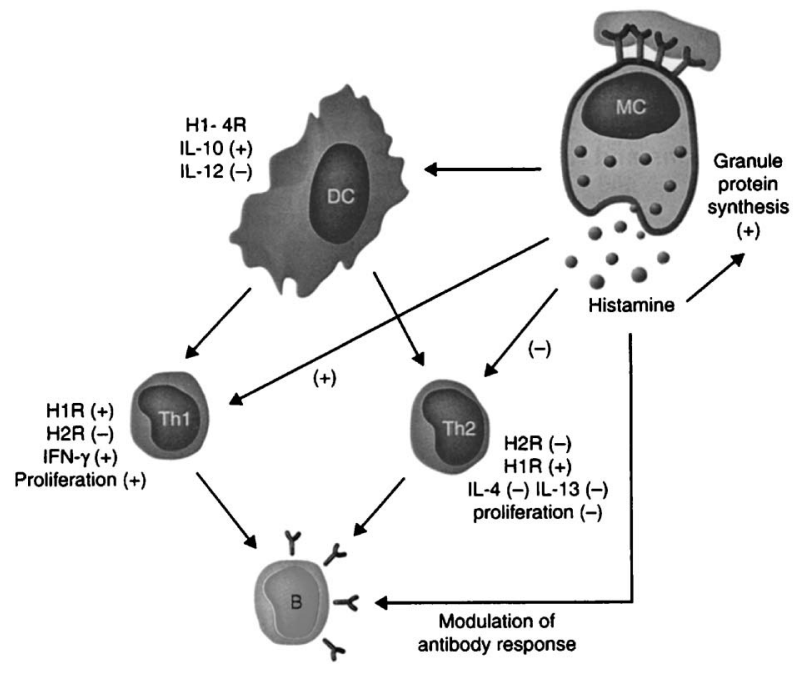

Fig. 4. Roles of Histamine in Immune Responses

そのサブタイプの特定方法により，H1RA の臨床 効果が優位になることも考えられる.

一方ヒスタミンの平滑筋収縮や浮腫といった作用 に加えて免疫への係わりが注目されてきている. ヒ スタミンは H1 及び H2 受容体を介して，樹状細胞，

Th1 及び Th2 リンパ球や B リンパ球に作用し, 特

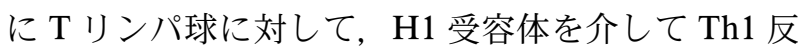
応を増強し, $\mathrm{H} 2$ 受容体を介して Th1 及び Th2 反 応を抑制することが明らかになってきた (Fig. 4). ${ }^{4)}$

これらのことを踏まえ，ヒスタミンが気管支喘息 の病態でどのような役割を果たしているかについて,
L-ヒスチジン脱炭酸酵素（HDC）遺伝子の欠損マ ウスを用いて，ヒスタミンが久損した状態での気管 支喘息でみられるアレルギー性気道炎症を観察し,

野生型マウス（C57BL/6）と比較した. ${ }^{5}$ ) 結果は OVA 感作後，HDC-KO マウスにおいて，OVA 曝 露後の気管支肺胞洗浄液（BALF）中 TNF- $\alpha$ 濃度 が野生型に比べ有意に高かった（Fig. 5)。また気 管支上皮細胞の杯細胞へ変換が有意に多かった (Figs. 6 and 7).このことは OVA 曝露によるアレ ルギー性炎症で肥満細胞やマスト細胞から産生され たヒスタミンが気道上皮細胞の杯細胞化を抑制して いることが推測される。 その機序として，H2レセ プターを介した TNF- $\alpha$ 産生細胞（単球やマクロフ アージ等）からの $\mathrm{TNF}-\alpha$ 産生抑制によるものでは ないかと考えている.

気道のヒスタミンの代謝にはヒスタミン $N$-メチ ルトランスフェラーゼ（HMT）が中心的な役割を 果たしている。しかし HMT は細胞内酵素であり， ヒスタミン分解のためにはヒスタミンを細胞内へ移 送する分子が必要である。 Organic Cation Transporter-3（OCT-3）は 12 回膜貫通型有機カチオン のトランスポーターで気道に特に発現が多く，ヒス タミンのトランスポーターと考えられている（Table 2). ヒト OCT-3 の遺伝子にはいくつかの多型 性がみられるが（Fig. 8)，エクソン 1 にある 120 番目のアルギニンの部分の塩基で $\mathrm{T}$ と $\mathrm{C}$ の変異が 

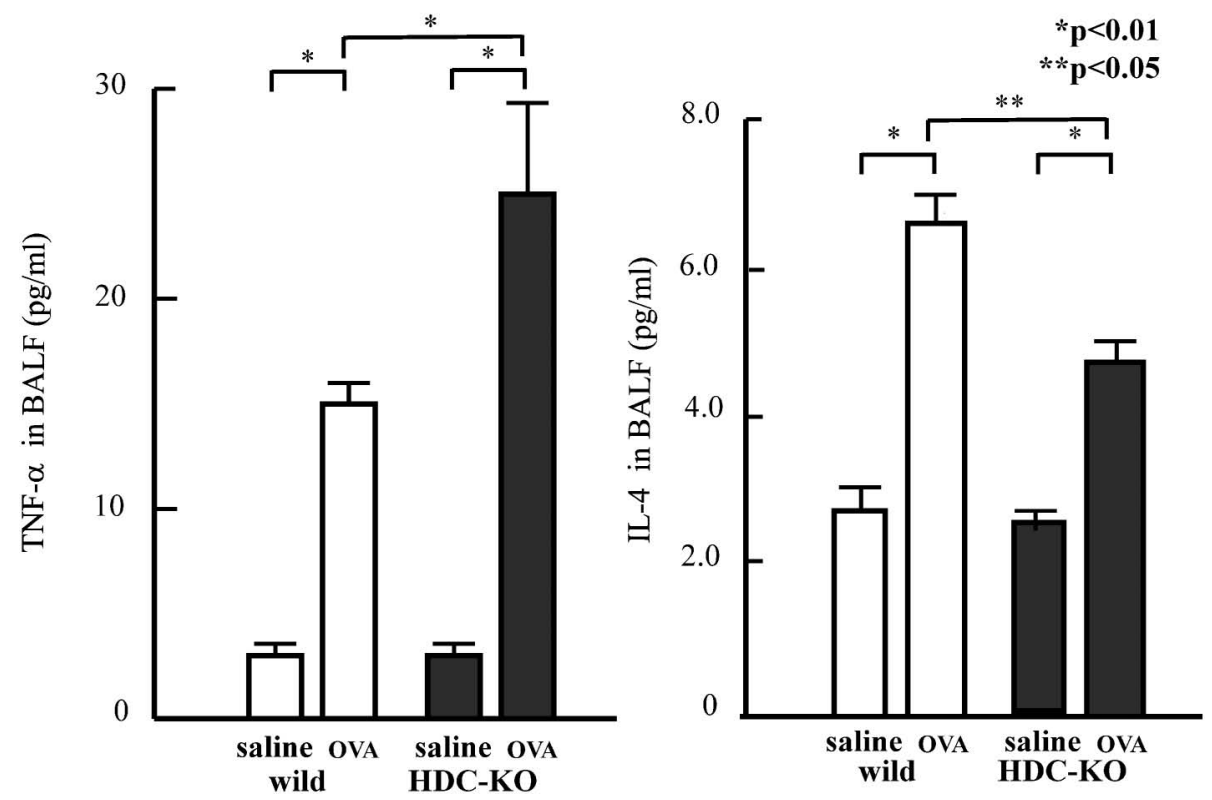

Fig. 5. Concentration of TNF- $\alpha$ and IL-4 in BALF

open column; wild type, closed column; HDC-KO (histamine deficient mice), saline; saline inhalation (control), OVA; ovalbumin inhalation (antigen challenge).
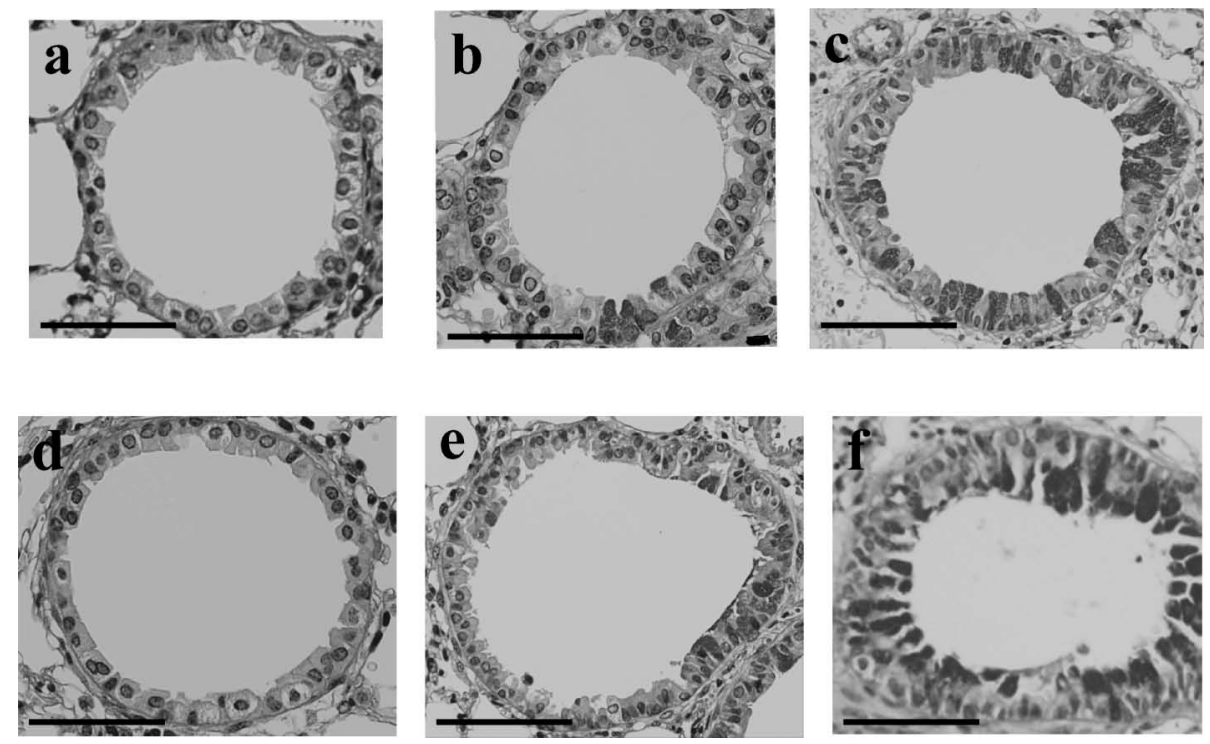

Fig. 6. Goblet Cells in the Small Airways (PAS Staining)

a, b, c: wild, d, e, f: HDC-KO (histamine deficient mice), a, d: control, b, e: saline, c, f: OVA, stained with PAS.

認められる.この変異はアミノ酸の変化は伴わない ものの, 軽症の喘息群と中等症/重症の喘息群では 有意の差があり, OCT-3 遺伝子の R120R（T/C） の変異は喘息の重症化に関与している可能性がある (Table 3). R120Rの TT のホモと CC のホモの患 者血液より単核球を調製して，培養液中で $0.1 \%$ $\mathrm{H}_{2} \mathrm{O}_{2}$ で酸化ストレスを与えると TT のホモの患者 においてのみ強い OCT-3 mRNAの上昇が観察され,
R120R の TT のホモと CC のホモではアミノ酸の変 異を伴っていなくても, 転写調節の違いが認められ た（Fig. 9)。アミノ酸の変化を伴わない塩基の変 異がごのように mRNA レベルに影響を与えるかに ついては，これまでいくつかの報告があるが，1つ は塩基の変化により mRNA の安定性に違いが出て くる場合や，同じアミノ酸をコードしていても用い られる tRNA が異なるためタンパク質の 3 次構造 


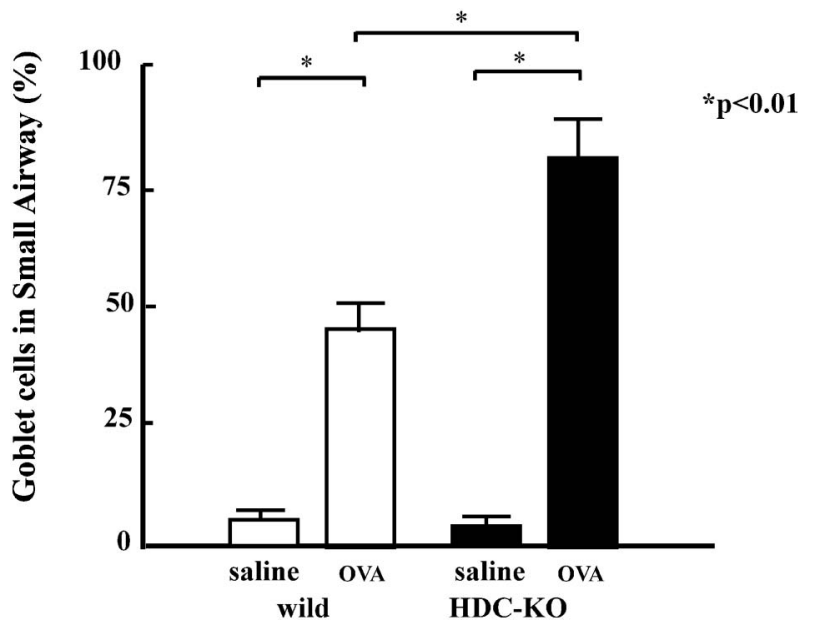

Fig. 7. Ratios of Goblet Cells in the Small Airway

open column; wild type, closed column; HDC-KO (histamine deficient mice), saline; saline inhalation (control), OVA; ovalbumin inhalation (antigen challenge).
に違いが出てくること等が考えられている（Fig. 10). ${ }^{6)}$

先に示したように，気管支喘息の治療ガイドライ ンでは H1 ブロッカーは補助的な位置におかれてい

Table 2. Characteristics of OCT3 Gene

- 12th cell membrane penetrating organic cation transporter

- Low affinity and selectivity

- Controling cation balance between of inner and outer cell environment

- Histamine is the most important substrate

- OCT3 has genomic imprinting

- Paternal imprinting (mice \& human)

Paternal gene is innactivated

$\rightarrow$ Only maternal gene is expressed

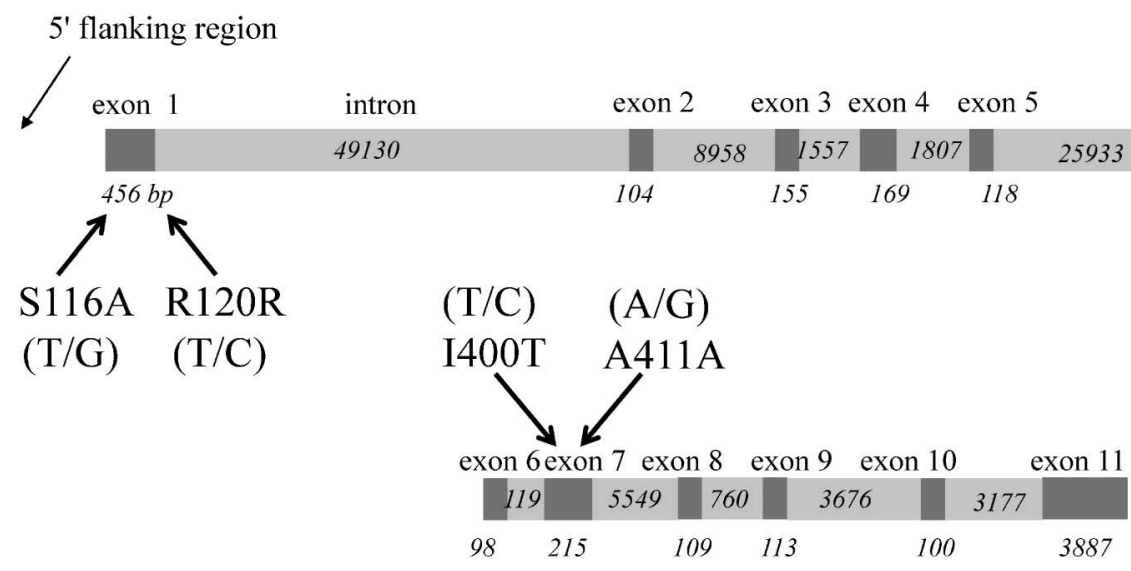

Fig. 8. Localization of SNPs in Human OCT3 (SLC22A3) Gene OCT3 (SLC22A3) is coded in 6th chromosome.

OCT3 regulation under $0.1 \% \mathrm{H}_{2} \mathrm{O}_{2}$ stimulation

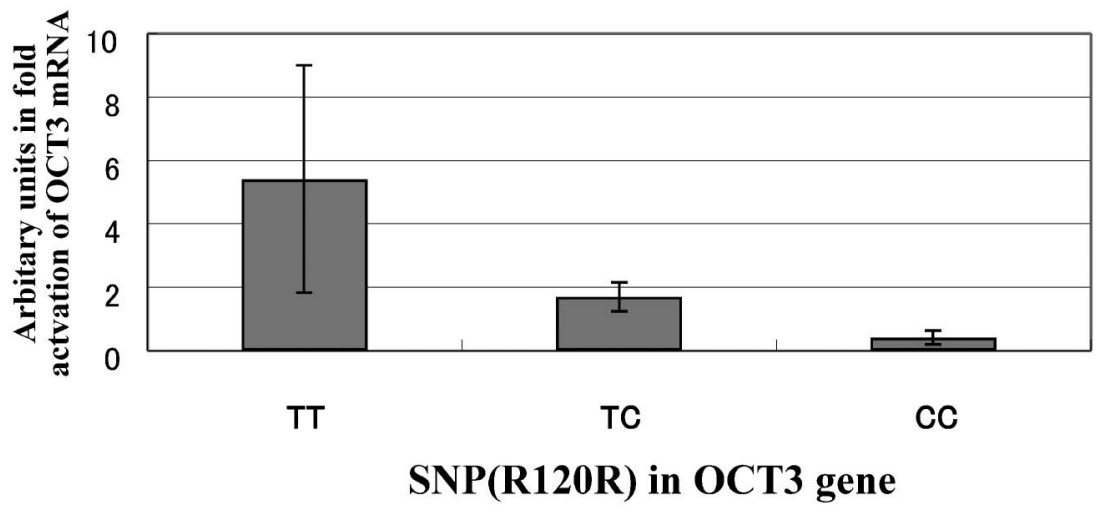

Fig. 9. Relationship between Oxidative Stress and Polymorphism of OCT3 Gene (Comparison between Gene Polymorphism and mRNA Level) 
Table 3. Analysis of Relationship between Asthma Severity and OCT3 Gene Polymorphism

\begin{tabular}{ccccc}
\hline \hline & アリル & \multicolumn{3}{c}{$\begin{array}{c}\text { 喘息群 } \\
\text { 中等症, 症群 } \\
\text { (Step 3, 4) }\end{array}$} \\
\hline \multirow{2}{*}{$\mathrm{R} 120 \mathrm{R}$} & $\mathrm{C}$ & 0.801 & & 0.698 \\
& $\mathrm{~T}$ & 0.190 & & 0.302 \\
$\mathrm{~A} 411 \mathrm{~A}$ & $p$ value & & 0.019 & \\
& $\mathrm{~A}$ & 0.460 & & 0.469 \\
& $\mathrm{G}$ & 0.540 & & 0.531 \\
& $p$ value & & 0.690 & \\
\hline
\end{tabular}

[Hypothesis 1]

Instability of OCT3 mRNA by oxidative stress

Decrease of OCT3 protein molecules

on cell surface

Decrease of histamine clearance
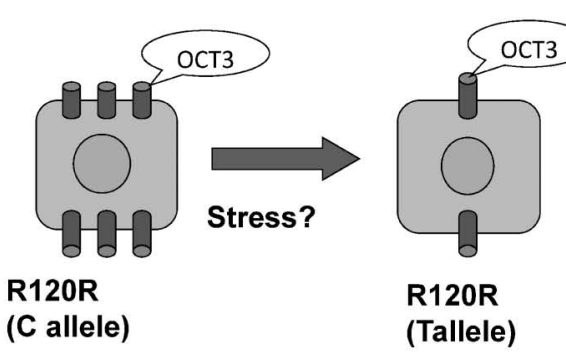

るが，アレルギー性鼻炎の治療ガイドラインでは中 心的な治療薬剤である。近年，アレルギー性鼻炎と 気管支喘息の合併について大規模な調査がわが国で も行われた. ${ }^{7)}$ そによると気管支喘息患者のアレ ルギー性鼻炎合併率は 70-80\% と極めて高く（Table 4)，両疾患の増悪時期は一致している（Fig. 11)。したがって，気管支喘息のコントロールのた めには，アレルギー性鼻炎のコントロールが必要で あるとの認識が広まっている，事実アレルギ一性鼻 炎と気管支喘息は部位が違うものの粘膜炎症は極め

\section{[Hypothesis 2]}

Difference of utilized tRNA despite coding same aminoacid

Change of 3 dimensional protein structure by different velocity of protein synthesis

Decrease of histamine clearance by altered protein function

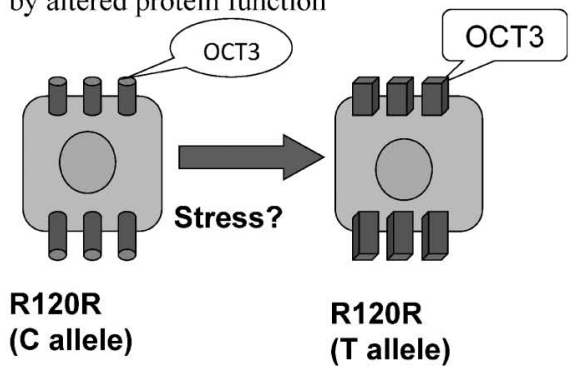

Fig. 10. Hypothesis: Relationship between SNP without Amino Acid Change and OCT3 Function

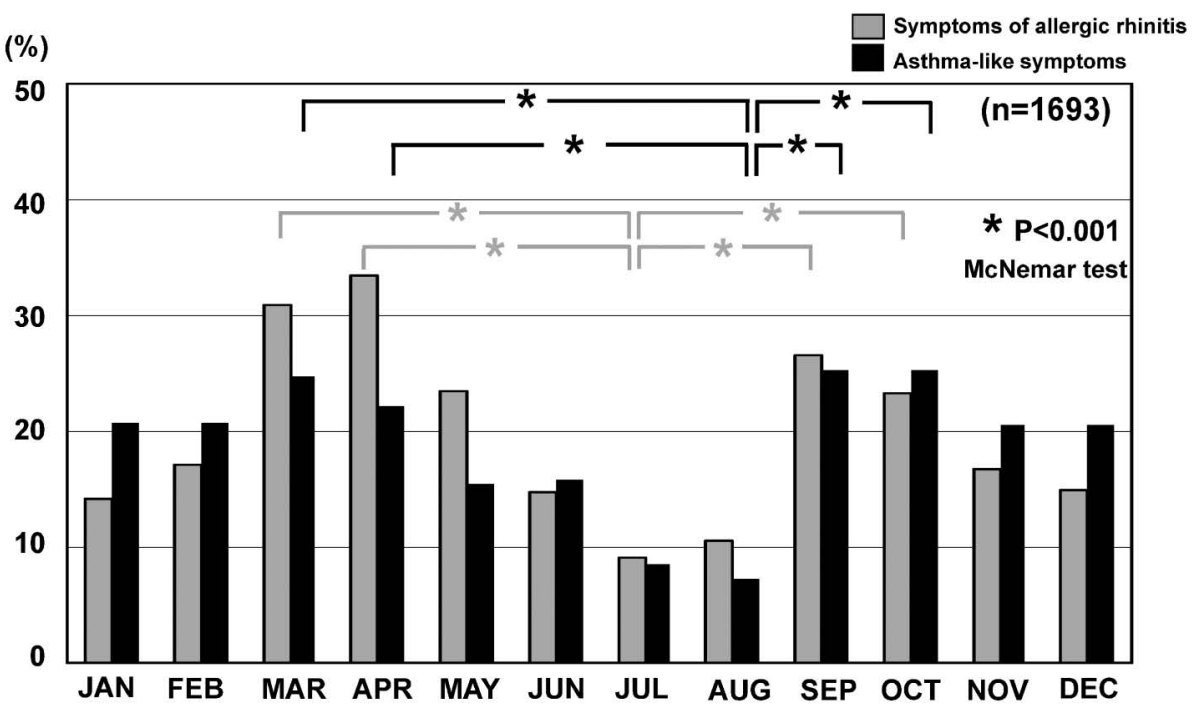

Fig. 11. Seasons of Frequent Occurrence of Asthmatic and Nasal Symptoms in Adult Asthmatics ${ }^{7)}$ Questions to patients with allergic rhinitis who have repeatedly developed asthma-like symptoms without having a cold. Q. Do you have aggravated symptoms of allergic rhinitis in specific months?

Q. In which months do you develop asthma-like symptoms? 
Table 4. Comorbidity of Bronchial Asthma and Allergic Rhinitis ${ }^{7)}$

\begin{tabular}{ccccc}
\hline \hline & 症例数 & \multicolumn{1}{c}{ ある } & ない & 無回答 \\
\hline 成人喘息 & 2781 & $1693(60.8 \%)^{*}$ & $1044(37.5 \%)$ & $44(1.6 \%)$ \\
小児喘息 & 3283 & $2238(68.2 \%)^{* *}$ & $1035(31.5 \%)$ & $10(0.3 \%)$ \\
アレルギー性鼻炎 & 3945 & $1935(49.0 \%)$ & $2010(51.0 \%)$ & 一 \\
\hline
\end{tabular}

Q. Question to asthma patients: Have you had an experience in which symptoms such as sneezing, runny nose and stuffy nose developed repeatedly when you did not have a cold?

Q. Question to patients with allergic rhinitis: Have you had an experience in which asthma-like symptoms such as a wheezing sound, cough, sputum, and exercise-induced breathing difficulty developed repeatedly when you did not have a cold?

* adult asthma $v s$. allergic rhinitis $p<0.001,{ }^{* *}$ child asthma $v s$. allergic rhinitis $p<0.001$ ( $\chi^{2}$ analysis).

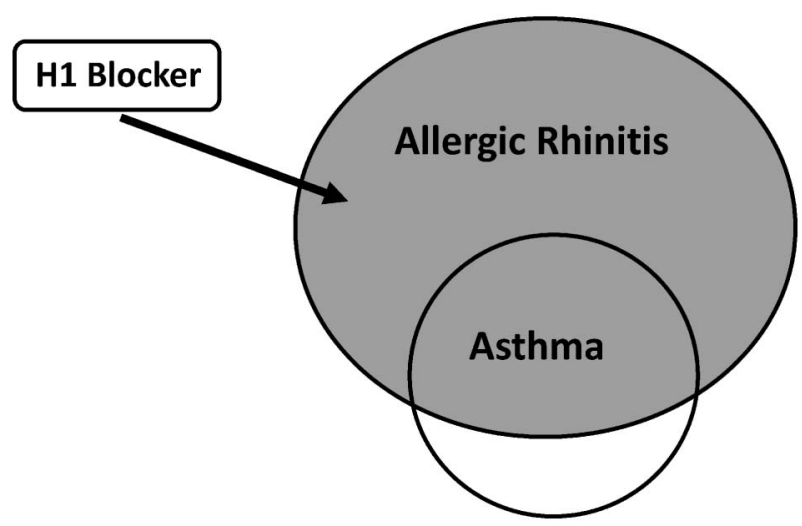

Fig. 12. Effective Uses of H1 Blockers against Complication of Bronchial Asthma and Allergic Rhinitis

て近似しており，同一疾患としての治療すべきとの 考え方が主流である。したがって，アレルギー性鼻 炎を合併した気管支喘息にとつて H1RA は臨床的 に重要な治療薬剤であると考えられる（Fig. 12）。

\section{REFERENCES}

1) Casale T. B., Wood D., Richerson H. B., Trapp S., Metzger W. J., Zavala D., Hunninghake G. W., J. Clin. Invest., 79, 1197-1203 (1987).
2) Rafferty P., Beasley R., Holgate S. T., Am. Rev. Respir. Dis., 136, 369-373 (1987).

3) Roquet A., Dahlén B., Kumlin M., Ihre E., Anstrén G., Binks S., Dahlén S.E., Am. J. Respir. Crit. Care Med., 155, 1856-1863 (1997).

4) Jutel M., Watanabe T., Akdis M., Blaser K., Akdis C. A., Curr. Opin. Immunol., 14, 735740 (2002).

5) Yamauchi K., Piao H. M., Nakadate T., Shikanai T., Nakamura Y., Ito H., Mouri T., Kobayashi H., Maesawa C., Sawai T., Ohtsu H., Inoue H., Allergol. Int., 58, 125-134 (2009).

6) Kimchi-Sarfaty C., Oh J. M., Kim I. W., Sauna Z. E., Calcagno A. M., Ambudkar S. V., Gottesman M. M., Science, 315, 525-528 (2007).

7) Yamauchi K., Tamura G., Akasaka T., Chiba T., Honda K., Kishi M., Kobayashi H., Kuronuma T., Matsubara A., Morikawa T., Ogawa H., Ohta N., Okada M., Sasaki M., Saito J., Sano K., Satoh M., Shibata Y., Takahashi Y., Takanashi S., Inoue H., Allergol. Int., 58, 55-61 (2009). 